\title{
地震リスクに対する構造・非構造・設備の影響度に着目した 建築物の耐震性能評価 \\ PERFORMANCE-BASED SEISMIC EVALUATION FOCUSED ON CONTRIBUTION OF STRUCTURAL FRAME, NON-STRUCTURAL ELEMENTS AND BUILDING EQUIPMENTS TO SEISMIC RISK
}

\author{
清水友香子*, 源栄正人**, 石田寛*** \\ Yukako SHIMIZU, Masato MOTOSAKA and Hiroshi ISHIDA
}

\begin{abstract}
This paper re-proposes a synthetic method of estimation of safety, reparability and serviceability for buildings from a viewpoint of seismic risk based on author etc (2010). The seismic risk curves regarding death rate, loss and building downtime are assumed to show safety, reparability, and serviceability in seismic performance. The effects of the interrelationship between the earthquake motion and the building response characteristics on each seismic risk were analyzed in detail. The results showed that, because the contribution of the structural frame, nonstructural elements, and building equipments to seismic risk was greatly affected by the interrelationship, there was a tradeoff relationship among the abovementioned seismic risks that depends on the evaluation conditions. This suggests the usefulness of determining seismic performance based on multifaceted seismic risk assessment.
\end{abstract}

Keywords : Seismic risk, Seismic performance, Ground motion amplification, Response spectrum method 地震リスク，而振性能，地盤増幅，応答スペクトル法

\section{1. はじめに}

近年，建築物の性能規定化に伴う研究および実践が国内外で広が りを見せている。米国では ATC581)において次世代性能設計の一環 として研究が進められ, 国内では 2000 年の建築基準法の改正によ り性能規定の考え方が浸透しつつある。それに伴い, 建築物の耐震 性能評価手法の一つである地震リスク評価技術に関する研究が増加 傾向にある。しかし，建築物は様々な性能に配慮した総合的なもの である 2)にも拘らず，地震リスク評価においては，デューデリジェ ンス等に用いられる $\mathrm{PML}^{3)}$ を一例として, 主に物的損失の一側面か ら耐震性能を推定することが多い。地震リスクに係る被害を多面的 に評価し, それらを総合して耐震性能を判断することができれば, 地震対策の意思決定を行う上で有意義である。

そこで，本研究では構造性能評価指針 2)において建築物の基本構 造性能として設定されている安全性, 修復性および使用性に関する 地震リスクを対象に，それらに関する地震リスクを総合した建築物 の耐震性能評価手法の構築を目的と寸る。ここで, 本研究では, 地 震リスクは「将来発生し得る地震により引き起こされる人間社会に 対する不利益の大きさとその発生確率の組合せ」と定義し, その切 り口として安全性, 修復性および使用性の観点からの評価項目を設
定することとする。

ところで, 過去の地震被害から地震動と建築物の振動特性の相互 関係が建築物の応答に深い関わりがあることが明らかにされている。 また，建築物の応答の中，応答変形は構造体および間仕切り等の非 構造部材の被害を, 応答加速度は設備機器および天井の被害を主に 生じさせると一般に理解されている。そこで, 本研究で提案する地 震リスク評価手法（耐震性能評価手法）は，建築物単体を対象とす るのではなく, 建築物周辺の地震環境および直下の地盤構造を考慮 して地震動の振動特性と建築物の振動特性の相互関係をきめ細かく 評価できるものとする。さらに，それらの相互関係に着目して地震 リスク評価結果に対する各構成要素（構造体，非構造部材および設 備機器）の被害特性を物理的に解釈した上で, 安全性, 修復性およ び使用性に関する各地震リスク評価結果（耐震性能評価結果）を詳 細に考察することも目的とする。これにより，提案手法の必要性を より強く主張できるものと考える。

なお，地震リスク評価手法は様々な形で提案されており例えば 4) 6), 地震動指標に着目すると, 最大地動, 地震応答スペクトルおよび地 震動の時刻歴波形を用いる手法に大別できる。最大地動を用いる手 法は扱いが簡便である反面，地震動や建築物の周期特性が反映され

\footnotetext{
* 鹿島技術研究所 研究員 · 博士 (工学)

** 東北大学大学院工学研究科 教授. 工博

*** 鹿島技術研究所 上席研究員 ·博士 (工学)
}

Research Engineer, Kajima Technical Research Institute, Dr. Eng.

Prof., Graduate School of Engineering, Tohoku University, Dr. Eng.

Chief Research Engineer, Kajima Technical Research Institute, Dr. Eng. 
にくく, 工学的な活用には必ずしも充分ではない。地震動の時刻歴 波形を用いる手法は比較的精緻な評価が可能であるが, 多くの手法 で多数の断層パラメータの確率モデルの設定を必要とし, そのモデ ル化に関する既往研究は充分とは言い難い。地震応答スペクトルを 用いる手法は震源の確率モデルに関する研究実績が豊富であり例えば 7), 建築物の応答解析も比較的簡単であることから, 本研究で対象 とするような地震動および建築物の振動特性の相互関係を考慮した 地震リスク評価を行う上では, 最も適している方法であると考えら れる。そこで, 本研究における提案手法は地震動評価から建築物応 答解析まで一貫して応答スペクトル法に基づくものとする。

本提案手法の考え方を図 1 に示す。
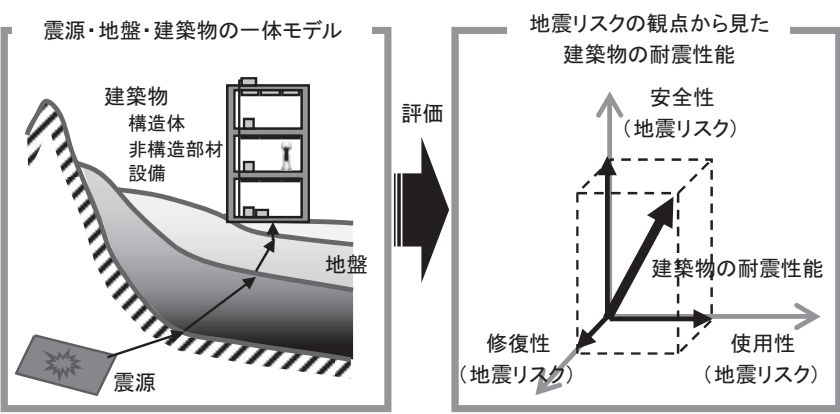

図 1 本提案手法の考え方

\section{2. 研究全体における本論文の位置づけ}

本論文では，地震リスクの観点からの安全性，修復性および使用 性を総合的に評価する手法を構築する。また，それを評価するため に必要な各性能に関する地震リスク評価手法をそれぞれ構築する。 さらに, パラメトリックスタディを通して, 地震動および建築物の 振動特性の相互関係が，耐震性能評価結果（地震リスク評価結果） および地震リスクに対する構造体, 非構造部材および設備機器の影 響度（地震リスク評価結果の大きさに対する各構成要素の寄与の大 きさ）に与える影響を詳細に考察する。

なお, 本研究に関連して, 著者らは文献 8)において, 従来から評 価されている損失率の地震リスク曲線を地震リスクの観点からの修 復性の評価項目として選定し, 地盤および建築物に関する評価条件 (計 64 ケース) が, 損失率の地震リスクの大きさおよびそれに対 する各構成要素の影響度に大きく影響することを確認している。ま た, 別途投稿中の論文において, 提案手法の実物件一の適用結果に 基づき地震リスク対策への展開可能性を検討している。本研究の全 体構成および本論文の位置付けを図 2 に示す。

本論文の構成は下記の通りである。

a) 建築物の耐震性能を構成する安全性, 修復性および使用性を地 震リスクの観点から解釈し，評価項目を設定寸る。(第 3 章)

b) 地震リスクの観点からの安全性, 修復性および使用性を総合し た建築物の耐震性能評価手法を定式化する。（第 4 章）

c）各性能に関する地震リスク評価手法を構築する。修復性に関す る地震リスクについては既報 8) と同様の手法とし, 安全性およ び使用性に関する地震リスクについては新たに評価手法を構 築する。(第 5 章 $)$

d) 地盤および建築物に関する複数の評価条件を用いてパラメト
リックスタディを行い, 評価結果を詳細に考察する。(第 6 章, 第 7 章)

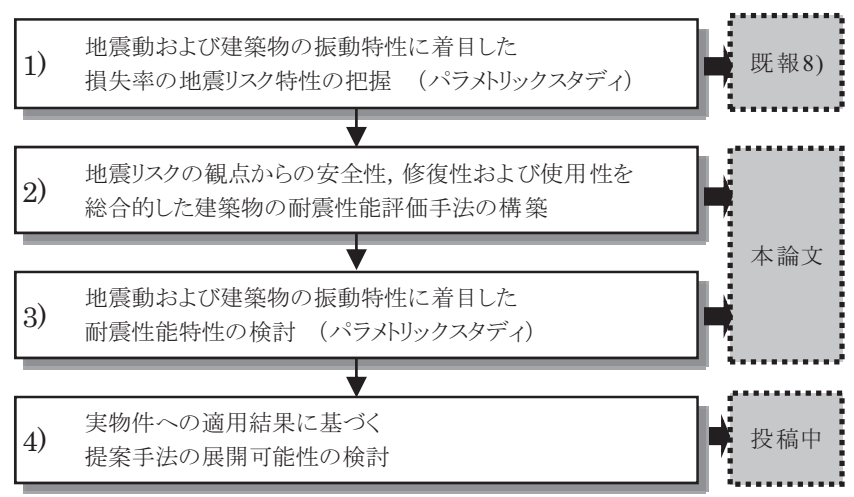

図 2 本研究の全体構成

\section{3． 地震リスクの観点からの耐震性能の解釈}

構造性能評価指針 2)では，安全性，修復性および使用性で構成さ れる基本構造性能を定義している。文献 2)に基づいて整理した各性 能要求の目的を表 1 に示す。

表 1 基本構造性能の定義（文献 2）に基づく）

\begin{tabular}{|l|l|}
\hline 基本構造性能 & 性能要求の目的 \\
\hline \hline 安全性 & $\begin{array}{l}\text { 建築物の内外の人の生命に直接及ぼす危険を回避す } \\
\text { る。（人命の保護） }\end{array}$ \\
\hline 修復性 & $\begin{array}{l}\text { 建築物が外部からの刺激に対して受ける損傷に対する } \\
\text { 修復のしやすさを磪保する。（財産の保全） }\end{array}$ \\
\hline 使用性 & $\begin{array}{l}\text { 建築物の機能, 居住性を確保する。（機能および居住 } \\
\text { 性の確保） }\end{array}$ \\
\hline
\end{tabular}

本論文では, 表 1 を踏まえた上で, 安全性, 修復性および使用性 の中の地震リスクの観点から評価可能な部分について以下のように 解釈寸る。なお，これらの解釈は既報 8 ) とは若干異なる。

a）地震リスクの観点からの安全性

建築物内の人命に直接及ぼす危険性に着目し，建築物内の滞 留人口に対する建築物の損傷による死者数の割合（以下，人的 被害率と呼ぶ）の大きさとその発生確率が安全性の一面を表わ すと仮定する。

b）地震リスクの観点からの修復性 :

地震による被害に対する修復のしや寸さは，修復費用により 表わした損失額と強い相関があると考えて, 再調達価格に対す る損失額の割合（以下，損失率と呼ぶ）の大きさとその発生確 率が修復性を表わすと仮定する。

c）地震リスクの観点からの使用性 :

地震時による建築物の機能の被害に着目し，建築物全体が使 用できない期間（以下，機能停止期間と呼ぶ）の大きさとその 発生確率が使用性の一面を表わすと仮定する。

以上の解釈の下，地震リスクの観点からの安全性，修復性および 使用性の評価項目として，人的被害率，損失率および機能停止期間 の超過確率曲線（以下，地震リスク曲線と呼ぶ）を設定する。 


\section{4 ．地震リスクに基づく耐震性能評価手法の構築}

\section{1 評価関数の定式化}

建築物の耐震性能は，地震リスクの観点からの安全性，修復性お よび使用性の 3 成分を合成した 1 本のベクトルにより表現されるも のと考える。この時，耐震性能の大きさは，例えばベクトルの長さ をとる方法, 3 成分の最大值をとる方法等, 様々な表現方法が考え 得る。つまり, 目的や意思決定者によって最適な指標は異なるため 一つに限定することは難しい。本論文では, 一つの案として, 最覀 の被害により耐震性能を定義することを意図し，3 成分の大きさの 最大值により定式化することとした。具体的には，まず安全性，修 復性および使用性として, 人的被害率，損失率および機能停止期間 の地震リスク曲線（超過確率曲線）を評価し，同じ超過確率におけ る地震リスクの大きさを算定する。次に, 各地震リスク評価結果の 大きさを意思決定者による許容值等から設定する基準值により除し (以下, 基準化と呼ぶ), 3 成分の尺度を揃える。最後に, 3 成分の 大きさの最大值を建築物の耐震性能として算出することとした。

以上より, 人的被害率 $x_{1}$, 損失率 $x_{2}$, 機能停止期間 $x_{3}$ の地震リス ク曲線を $p=f_{1}\left(x_{1}\right), p=f_{2}\left(x_{2}\right), p=f_{3}\left(x_{3}\right)$ とおき, 各性能を総合した建築 物の耐震性能 $x$ の地震リスク曲線を $p=Z(x)$ とおくと, 超過確率 $p_{0}$ に 対する建築物の耐震性能の大きさ $x=Z^{-1}\left(p_{0}\right)$ は次式により示される。

$$
Z^{-1}\left(p_{0}\right)=\max \left(\frac{f_{1}^{-1}\left(p_{0}\right)}{\alpha_{1}}, \frac{f_{2}^{-1}\left(p_{0}\right)}{\alpha_{2}}, \frac{f_{3}^{-1}\left(p_{0}\right)}{\alpha_{3}}\right)
$$

ここに, $f_{1}^{-1}\left(p_{0}\right), f_{2}^{-1}\left(p_{0}\right), f_{3}^{-1}\left(p_{0}\right)$ は超過確率 $p_{0}$ に対する人的被害率, 損失率，機能停止期間の地震リスクの大きさであり， $\alpha_{1}, \alpha_{2}, \alpha_{3}$ は 人的被害率，損失率および機能停止期間に関する基準值である。

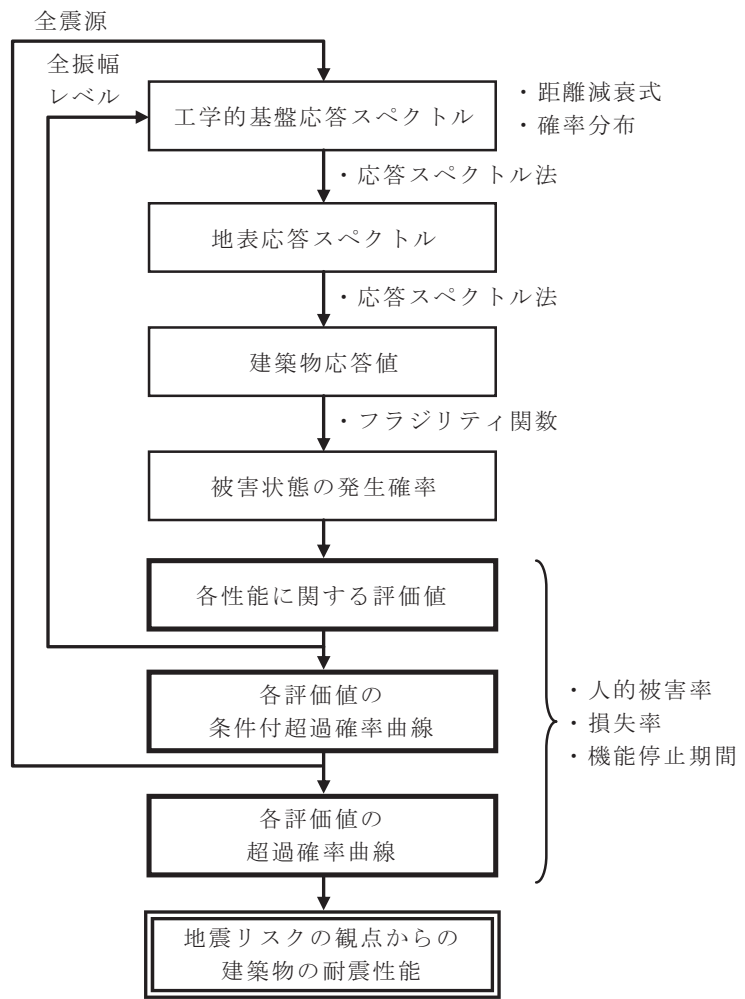

図 3 評価手順の概略フロー

\section{2 評価フロー}

地震リスクの観点からの安全性, 修復性および使用性を総合した 建築物の耐震性能評価手法の概略フローを図 3 に示す。ここで, 損 失率の地震リスク評価手法は既報 ${ }^{8)}$ と同様とする。また，人的被害 率および機能停止期間の地震リスク評価手法は，図 3 における “被 害状態の発生確率”の評価までは損失率と共通とし, それ以降の評 価式を新たに構築する。

なお，図 3 からも分かるように，本評価手法に関わる要素技術は 多岐に渡る。そのため，入力情報や要素技術の整合性に留意して評 価手法を構築する。また，式(1)に示したように最終結果である耐震 性能は, 各性能に関する地震リスクの大きさを比較してその最大值 を取るため, 各評価手法の詳細さが同程度になることにも留意する。 評価手法の詳細は次章に示す。

\section{5。各性能に関する地震リスク評価手法}

後述するパラメトリックスタディにおける評価条件の中の基準分 一スを例として, 損失率，人的被害率および機能停止期間の地震リ スク評価手法を以下に示寸。

\section{1 損失率の地震リスク評価手法}

（1）工学的基盤応答スペクトルの算定 a)震源モデルの設定

震源モデルは地震調查研究推進本部 9)（以下，地震本部と呼ぶ） に基づき，日本全国の活断層，海溝型地震および領域震源（震源断 層を予め特定しにくい地震) に関して，地震発生確率，震源位置お よび規模等を設定する。

b)工学的基盤応答スペクトルの確率分布の算定

特定の地震により発生する工学的基盤応答スペクトルの中央值は 内山ら 10)の距離減衰式を用い, 対数正規分布に従ってばらつくと仮 定する。対数標準偏差 $\beta$ は 0.4 を設定する。次に，対数正規分布の 裙の打切りを $\pm 2 \beta$ と設定し，その範囲内を対数軸上で 15 区間に等 分割し, さらに各区間の中央值により 15 個の振幅レベルの応答ス ペクトルに離散化する。これは，応答スペクトル值は周期間で完全 相関を仮定したことになる。また，打切り範囲内の全確率は 1.0 に なるように調整する。

（2）地表応答スペクトルの算定

a)地盤構造モデルの設定

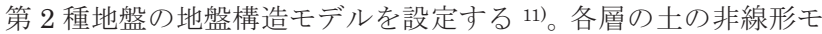
デル（動的変形特性曲線）は Hardin-Drnevich（H-D） モデル ${ }^{12}$ を採用する。地盤モデルを表 2 に，H-D モデルを図 4 に示す。

b)地盤応答解析

地盤応答解析は，地盤の質点系モデルのモード解析に基づく石田 ら ${ }^{6}$ による応答スペクトル法を用いる。なお，この方法は一次元波 動論に等価線形化法を適用した場合と同等であることが確かめられ ている 13)。また，地盤の質点系モデルは 0.1s 以上の周期帯域を対 象としているが，それより短周期側においても評価結果の誤差は比 較的小さいことが確認されている6)。

（3）建築物のモデル化

a)多質点系モデルの設定

$\mathrm{RC}$ 造の事務所ビルを想定する。各階が勒性部材で構成される多 質点系モデルを設定し，各階の復元力特性モデルは図 5 に示寸よう 
な 3 折線モデルを仮定する。第 2 折点の降伏時せん断力 $Q_{y}$ はベー スシア係数 $C_{b}$ と $\mathrm{Ai}$ 分布により設定する。 $C_{b}$ は 0.3 とし, 第 2 折点 の降伏時層間変形角は $1 / 150$ とする。また, 初期減衰は $3 \%$ を設定 寸る ${ }^{14)}$ 。建築物の階数は 3 階建とし, 各階の階高は一律 $3.5 \mathrm{~m}$ とす る。基礎の平面形状は $30 \mathrm{~m} \times 30 \mathrm{~m}$ とし, 埋込み深さは $2 \mathrm{~m}$ と仮定す る。また, 基礎の質量は考慮しない。その他の条件は図 5 に示した。 b)等価一質点系モデルへの縮約

静的荷重増分解析により基礎固定時の等価 1 質点系に縮約する。 ここでは, 建築物応答は等価線形系における 1 次モードが支配的で あると考え, 弾性時の 1 次固有モード形を固定する。次いで, 得ら れた結果を 3 折線モデルに近似する。

c)地盤ばねの算定

基礎固定時の復元力モデルと地盤ばねを用いて，スウェイーロッ キングモデル（SR モデル）を設定する。ここで, 基礎に付く水平 と回転の動的地盤ば叔は, 限界耐力計算法 ${ }^{14)}$ と同様に, 2 層地盤の

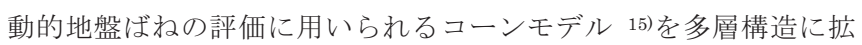
張した方法で算定する。

\section{(4) 建物応答解析}

建築物の最大応答（変形角および加速度）は，等価 1 質点系をべ ースとする耐力スペクトル法により算定する。ここでは, 限界耐力

表 2 地盤構造モデル

\begin{tabular}{|c|c|c|c|c|c|c|}
\hline & $\begin{array}{c}\text { 底面深度 } \\
\mathrm{D}(\mathrm{m})\end{array}$ & $\begin{array}{c}\text { 層厚 } \\
\mathrm{H}(\mathrm{m})\end{array}$ & $\begin{array}{c}\text { 密度 } \\
\rho(\mathrm{t} / \mathrm{m} 3)\end{array}$ & $\begin{array}{c}\mathrm{S} \text { 波速度 } \\
\mathrm{Vs}(\mathrm{m} / \mathrm{s})\end{array}$ & $\begin{array}{c}\mathrm{P} \text { 波速度 } \\
\mathrm{Vp}(\mathrm{m} / \mathrm{s})\end{array}$ & 土質 \\
\hline \hline 1 & 4.5 & 4.5 & 1.8 & 90 & 1360 & 粘性土 \\
\hline 2 & 10.0 & 5.5 & 1.6 & 150 & 1560 & 砂質土 \\
\hline 3 & 17.0 & 7.0 & 1.8 & 210 & 1560 & 砂質土 \\
\hline 4 & 18.5 & 1.5 & 1.7 & 150 & 1560 & 粘性土 \\
\hline 5 & 25.0 & 6.5 & 1.8 & 260 & 1560 & 砂質土 \\
\hline 工学的基盤 & & & 1.8 & 390 & 1700 & \\
\hline
\end{tabular}

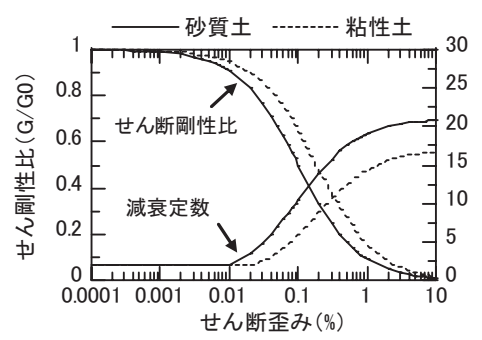

図 4 動的変形特性曲線（H-D モデル）

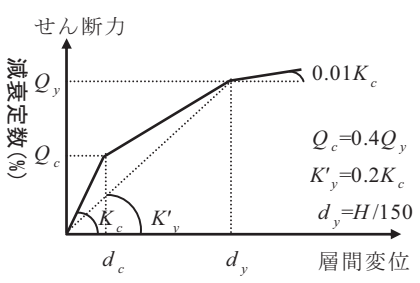

図 5 多質点系モデル
表 3 フラジリティ関数のパラメータ

構造体: Structural

\begin{tabular}{|c|c|c|c|c|}
\hline & Slight & Moderate & Extensive & Complete \\
\hline 損傷割合 & $2 \%$ & $10 \%$ & $50 \%$ & $100 \%$ \\
\hline 層間変形角（中央値） & 0.005 & 0.01 & 0.03 & 0.08 \\
\hline 対数標準偏差 & 0.81 & 0.84 & 0.86 & 0.81 \\
\hline \multicolumn{5}{|l|}{ 非構造部材（変形依存型） } \\
\hline & Slight & Moderate & Extensive & Complete \\
\hline 損傷割合 & $2 \%$ & $10 \%$ & $50 \%$ & $100 \%$ \\
\hline 層間変形角（中央値） & 0.004 & 0.008 & 0.025 & 0.05 \\
\hline 対数標準偏差 & 0.84 & 0.88 & 0.9 & 0.88 \\
\hline \multicolumn{5}{|l|}{ 非構造部材（加速度依存型） } \\
\hline & Slight & Moderate & Extensive & Complete \\
\hline 損傷割合 & $2 \%$ & $10 \%$ & $30 \%$ & $100 \%$ \\
\hline 床応答加速度（中央值，g） & 0.3 & 0.6 & 1.2 & 2.4 \\
\hline 対数標準偏差 & 0.68 & 0.68 & 0.67 & 0.67 \\
\hline
\end{tabular}

法 ${ }^{14)}$ と同様に，基礎一地盤の連成系による固有周期の伸びと減衰定 数の増大を取り入れることにより相互作用を考慮する。なお，縮約 $\mathrm{SR}$ モデルの等価高さおよび等価質量は，簡単のため基礎固定時の 静的荷重増分解析における弾性時の值を用いる。次いで，等価一質 点系で評価した応答值から静的荷重増分解析結果を用いて各階の層 間変形角および床応答加速度を推定する。

(5) 損失評価

a)フラジリティ関数の設定

フラジリティ関数を用いて, 各階の建築物応答から各構成要素に おける被害状態の発生確率を算定する。ここで, 被害状態とは, 倒 壊あるいは全壊 (Complete), 大破 (Extensive), 中破 (Moderate), 小破（Slight）および軽微以下（None）である。フラジリティ関数 は米国の被害想定ツールとして普及している HAZUS'16)のデータを 適用し，その中の RC ラーメン構造で High-Code のデータを設定す る。対数正規分布でモデル化されたフラジリティ関数のパラメータ を表 3 に示す。この中, 構造体, 非構造部材および設備は, それぞ れ表 3 の構造体，非構造部材（変形依存型）および非構造部材（加 速度依存型）を用いる。

b)損傷割合の設定

被害状態に対応する損傷割合 (Complete の損失額を $100 \%$ とした 時の各被害状態における損失額の割合）は，HAZUS16)のデータを 採用する。採用した損傷割合を表 3 に併せて示した。

c)再調達価格モデルの設定

再調達価格割合は HAZUS ${ }^{16)}$ の COM4（事務所ビルを想定してい る）のデータを用いる。設定した再調達価格割合は構造体 $19.2 \%$, 非構造部材 $32.9 \%$, 設備機器 $47.9 \%$ であるなお, 階ごとの再調達 価格割合は，各構成要素が各階に均等に分配されているものと仮定 して設定する。

d)損失評価

各階の各構成要素における各被害状態の発生確率と損傷割合を用 いて，建築物全体の損失率の平均值を評価する。ここで，各構成要 素の被害発生は独立に扱うが，構造体が倒壊（Complete）の場合は 非構造部材および設備機器も全壊（Complete）と仮定する。また， 各階における損失は簡単のため独立に発生すると仮定する。

（6）損失率の地震リスク曲線の算定

震源は全て独立に発生すると仮定すると, 全震源による $t$ 年間の 損失率 $z$ の地震リスク曲線は次式により評価できる。

$$
P(z ; t)=1-\prod\left\{1-P_{i}(z ; t)\right\}
$$

ここに, $i$ は震源, $P_{i}(z ; t)$ は $t$ 年間における震源 $i$ による損失率 $z$ の 超過確率である。

また, $P_{i}(z ; t)$ は複数回の地震発生を無視すると, 次式により算出 される。

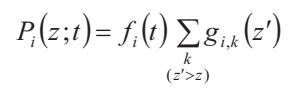

ここに, $f_{i}(t)$ は $t$ 年間の震源 $i$ の地震発生確率, $g_{i, k}\left(z^{\prime}\right)$ は震源 $i$ に よる地震が発生したという条件の下での振幅レベル $k$ の応答スペク トルにより生じる損失率 $z^{\prime}$ の発生確率である。

なお，連動を考慮する海溝型地震の場合は複数の地震発生パター ンを考慮し，次式により算出する。 


$$
P_{i}(z ; t)=\sum_{n} f_{i, n}(t) \sum_{\substack{k \\\left(z^{\prime}>z\right)}} g_{i, n, k}\left(z^{\prime}\right)
$$

ここに, $f_{i, n}(t)$ は $t$ 年間の海溝型地震 $i$ の発生パターン $n$ の地震発生 確率, $g_{i, n, k}\left(z^{\prime}\right)$ は海溝型地震 $i$ の発生パターン $n$ が起こったという条 件の下での, 振幅レベル $k$ の応答スペクトルにより生じる損失率 $z^{\prime}$ の発生確率を示す。

\section{2 人的被害率の地震リスク評価手法}

(1) 評価項目

地震対策に係る意思決定において人命保護は最優先項目であるに も拘らず，対策支援の一手段である地震リスク評価において人的被 害を扱った既往研究は少ない。一方, 特定の地震による人的被害評 価については, 過去の地震被害に関する調查および分析を行った研 究例えば 17), 地震による地域の死者・負傷者率の予測式を経験的に評 価した研究例えば 18 , 地震の摇れによる室内環境の変容と人間行動を 考慮した人的被害評価に関する研究例えば19)等が行われている。

本論文では, 既往研究における兵庫県南部地震の人的被害の分析 結果を用いて, 人的被害率（対象建築物における全滞留人口に対す る死者数の割合）の地震リスク評価手法を構築する。

(2) 評価式の構築

地震 $i$ により, 振幅レベル $k$ の地表応答スペクトルが発生した場 合の対象建築物内における死者数 $d_{i, k}$ は次式により評価する。

$$
d_{i, k}=\sum_{m=1}^{N_{M}} n_{m} \cdot g_{m} \cdot P\left\{B_{m} \mid D_{m, 1}\right\} \cdot P\left\{D_{m, 1} \mid s_{i, k}\right\}
$$

ここに, $N_{M}$ は建築物の階数, $n_{m}$ は $m$ 階における滞留人口, $D_{m, 1}$ は $m$ 階における構造体が大破以上となる確率変数 $(=1$ : 事象発生, $=0:$ 事象発生しない), $B_{m}$ は $m$ 階において死者が発生する確率変数 $\left(=1\right.$ : 事象発生, $=0$ : 事象発生しない) であり, $P\left\{D_{m, 1} \mid s_{i, k}\right\}$ は地震 $i$ により振幅レベル $k$ の地表応答スペクトル $s_{i, k}$ が発生した場合に $D_{m, 1}$ が発生する確率, $P\left\{B_{m} \mid D_{m, 1}\right\}$ は $D_{m, 1}$ が生じたという条件の下で $B_{m}$ が発生する確率, $g_{m}$ は $B_{m}$ が発生した場合の $m$ 階の滞留人口に対 する死者数の割合である。

人的被害率 $y^{\prime}$ は, 式(5)により算出した死者数を建築物全体の滞留 人口で除して算定する。

式(5)における $P\left\{D_{m, l} \mid s_{i, k}\right\}$ は損失率の評価で用いたフラジリティ関 数（表 3) により算定する。また, 各階の $n_{m}$ は全階において同值と する(これにより, 人的被害率を求める際に式(5)の $n_{m}$ は打ち消さ れるため具体的な值は必要としない)。さらに, $P\left\{B_{m} \mid D_{m, l}\right\}$ および $g_{m}$ の值は, 兵庫県南部地震の被害分析結果 20 ) 22) 基に以下のように 設定した。

$$
\begin{aligned}
P\left\{B_{m} \mid D_{m, 1}\right\} & = \begin{cases}0.025 & : D_{m, 1}=1 \\
0 & : D_{m, 1}=0\end{cases} \\
g_{m} & = \begin{cases}0.5 & : B_{m}=1 \\
0 & : B_{m}=0\end{cases}
\end{aligned}
$$

なお, 本論文では, 地震リスクの観点からの安全性に係る評価項 目として構造体による死者数を評価したが, 負傷者数の評価や非構 造部材の落下・落床および家具転倒による人的被害も重要な要素で あると思われる。また, 式(5)は兵庫県南部地震の被害分析結果を基 にしたが, 当地震による被害は大半が自宅内で発生したものと推測 され, 本研究で対象とする事務所ビルにおける評価式としては検討 の余地が残されている。これらに関しては今後の課題としたい。
（3）人的被害率の地震リスク曲線の算定

式(2)〜式(4)における損失率 $z^{\prime}$ を人的被害率 $y^{\prime}$ に置き換えて, 損失 率の地震リスク曲線と同様に算出する。

\section{3 機能停止期間の地震リスク評価手法}

(1) 評価項目

企業における事業継続計画の策定に向けた取り組みを背景に，地 震時の機能の復旧期間評価に関する研究が増加傾向にある。地震時 の復旧曲線（地震後の経過日数に対する機能の回復率を表わしたも の）の評価を主目的とした研究例えば 23) 25), Fault Tree Analysis と 対比させ地震時の機能停止期間の確率関数を簡便に求める手法を提 案した研究 26)などが行われている。

本論文では, 安全性および修復性の評価手法とのバランスを考慮 し煩雑なモデル化を行わずに評価することを前提の上，復旧曲線に より定義される機能停止期間の地震リスク曲線を簡便に算出する新 たな方法を構築する。

(2) 評価式の構築

復旧曲線は, 一般に横軸に経過日数, 縦軸に地震前の機能を 1.0 とした時の機能回復率で表わされ, 復旧曲線の左側の面積によって 復旧に掛かる日数の期待值が求められる。本論文では, 復旧曲線を 図 6 に示すような台形で近似し，その面積により機能停止期間を定 義することとした。また，本論文では復旧曲線を用いずに建築物の 復旧に掛かる日数や機能の回復具合のばらつきを考慮するため, 台 形の面積で近似した機能停止期間を確率論的に評価する。以下, 評 価式を示寸。なお, 本項の評価式は全て「地震 $i$ による振幅レベル $k$ の地表応答スペクトルが発生した」という条件の下での議論であ り，以下この条件に関する記述は省略するものとする。

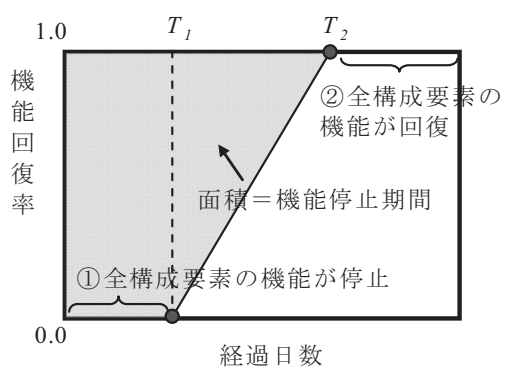

図 6 機能停止期間の評価式

今, 何れかの構成要素が復旧した経過日数（図 6 の $T_{1}$ ) の条件付 超過確率曲線を $g_{1}(t)$ とおくと, $g_{1}(t)$ は $T_{1}$ が経過日数 $t$ を超える確率 であり, 即ち図 6 の(1)の範囲に $t$ がある確率と見なせる。その確率 は, 各階の各構成要素は独立であると仮定すると, 全構成要素の機 能が停止している確率として次式により表せる。

$$
g_{1}(t)=\prod_{m=1}^{N_{M}} \prod_{j=1}^{N_{m, j}} P\left\{R_{m, j}(t) \mid s_{i, k}\right\}
$$

ここに, $N_{M}$ は建築物の階数, $N_{m, J}$ は $m$ 階における構成要素数であ る。また, $P\left\{R_{m, j}(t) \mid s_{i, k}\right\}$ は地震 $i$ により振幅レベル $k$ の地表応答スペ クトル $s_{i, k}$ が発生した場合に $m$ 階の構成要素 $j$ の機能が経過日数 $t$ において停止している確率である。

また, 全構成要素が復旧した経過日数（図 6 の $T_{2}$ ) の条件付非超 過確率曲線を $h_{2}(t)$ とおくと, $h_{2}(t)$ は図 6 の(2)の範囲に $t$ がある確率 
と見なせる。その確率は全構成要素の機能が回復した確率として, 各階の各構成要素は独立であると仮定すると, 次式により表せる。

$$
h_{2}(t)=\prod_{m=1}^{N_{M}} \prod_{j=1}^{N_{m, j}}\left(1-P\left\{R_{m, j}(t) \mid s_{i, k}\right\}\right)
$$

従って, $T_{2}$ の条件付超過確率曲線 $g_{2}(t)$ は次式で示される。

$$
g_{2}(t)=1-h_{2}(t)=1-\prod_{m=1}^{N_{n}} \prod_{j=1}^{N_{m, j}}\left(1-P\left\{R_{m, j}(t) \mid s_{i, k}\right\}\right)
$$

機能停止期間の条件付超過確率曲線を $p(e)$ とおくと, 超過確率 $p_{0}$ における機能停止期間の大きさは台形の面積（図 6) として, 次 式により算出することとする。

$$
p^{-1}\left(p_{0}\right)=\frac{1}{2}\left\{g_{1}^{-1}\left(p_{0}\right)+g_{2}^{-1}\left(p_{0}\right)\right\}
$$

機能停止期間 $e^{\prime}$ は, 式(7)および式(9)を式(10)に代入することによ り求められた機能停止期間の条件付超過確率曲線と両軸で囲まれた 面積（期待值）により算定する。

次に, 式(7)および式(9)における各構成要素の $P\left\{R_{m, j}(t) \mid s_{i, k}\right\}$ の算出 式を考える。考慮する構成要素は, 構造体, 非構造部材, 電気設備 および給排水・衛生設備とする。ここで, 本来事務所ビルにおいて は数多くの設備機器が係わるが, 本研究では建築物における全設備 機器が同時並行して修復工事を行うと仮定した場合に機能停止期間 が比較的大きいと考えられるものを選定した。

電気設備および給排水・衛生設備の $P\left\{R_{m, j}(t) \mid s_{i, k}\right\}$ については関連す る要素設備を考慮する例﨎ば 23$)$ 。事務所ビルに多い給水方式として高 置水槽方式, 受変電設備は 1 階電気室にある建築物を想定し, 同一 階における同一種類の要素設備の被害は完全相関と仮定し, 一般的 な設備系統図として図 7 および図 8 に示寸モデルを設定した。図に おいて, 例えば 1 階照明設備は, 受変電設備 $\rightarrow 1$ 階分電盤 $\rightarrow 1$ 階照 明設備が要素設備であることを示す。また，○の大きさは後述する 修復期間の大きさを相対的に示している。各階の電気設備, 給排水・ 衛生設備の機能停止確率 $P\left\{R_{m, j}(t) \mid s_{i, k}\right\}$ は, それを構成寸る何れかの要 素設備の機能が停止する確率として算出する。

構造体, 非構造部材および設備機器（電気設備, 給排水・衛生設 備）における各要素設備の機能停止確率は, 経過日数と機能停止確 率の関係（以下, 機能停止確率モデルと呼ぶ）により算出する。機 能停止確率モデルは, (1)フラジリティ関数を用いて被害状態の発生 確率を算定し，(2)被害状態に対応した修復期間を設定し，(3)経過日 数が(2)で設定した修復期間未満の場合は機能停止として機能停止確 率は(1)の值, 経過日数がそれ以降の場合は回復として機能停止確率 はゼロとし, 経過日数と機能停止確率の関係を設定する。被害状態
に対応した修復期間を表 4 に示す。ここで，構造体に関する修復期 間は HAZUS16)の COM4（事務所ビルを想定）のデータを用いた。 構造体の機能停止確率モデルの設定例を図 9 に示す。また, フラジ リティ関数は構造体および非構造部材については損失率の評価と同 様とする。電気設備および給排水・衛生設備における各要素設備も 同様に HAZUS ${ }^{16)}$ )のデータを用い, 配管のみ非構造部材 (変形依存 型）とし，それ以外の殆どは非構造部材（加速度依存型）を用いる。 （3）機能停止期間の地震リスク評価手法

式(2)〜式(4)における損失率 $z^{\prime}$ を機能停止期間 $e^{\prime}$ に置き換えて, 損 失率の地震リスク曲線と同様に算出する。

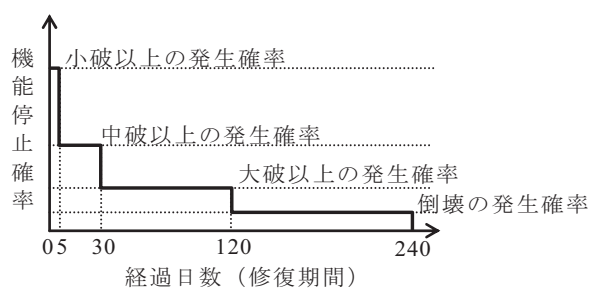

図 9 機能停止確率モデルの設定例

\section{6. 適用例}

\section{1 建築物モデルの違いによる耐震性能評価結果への影響}

(1) 評価条件

ベースシア係数 $C_{b}$ を $0.3 \sim 1.0$ まで 0.1 刻みで計 8 通りの建築物 モデルを設定する。震源, 地盤および建築物に関するその他の評価 条件は第 5 章に示した通りである。

（2）各性能に関する地震リスク曲線（評価結果）

各建築物モデルについて，人的被害率，損失率および機能停止期 間の地震リスク曲線を評価した。地震リスク曲線およびそれにおけ る 50 年超過確率 $80 \%, 50 \%, 20 \%, 10 \%$ おび $5 \%$ の地震リスク值 の変化を図 10 に示寸。図から, 人的被害率の地震リスクの大きさ は，何れの超過確率レベルにおいても， ベースシア係数 $C_{b}$ （耐力） が大きくなるほど低減している様子が認められる。一方，損失率に ついては，50 年超過確率 $50 \%$ および $80 \%$ の地震リスク值は極大值 を持ち, それ以上の地震動レベル（50 年 $20 \% ， 10 \% ， 5 \%$ 超過值） では単調増加している。機能停止期間については, 50 年超過確率 $80 \% ， 5 \%$ の地震リスク值はローカルな極大值を持ち， $50 \% ， 20 \%$ お よび $10 \%$ の地震リスク值は単調増加している。このように，人的被 害率，損失率および機能停止期間の地震リスクはそれぞれ異なる変 化をみせる。損失率および機能停止期間の地震リスクの一部で耐力

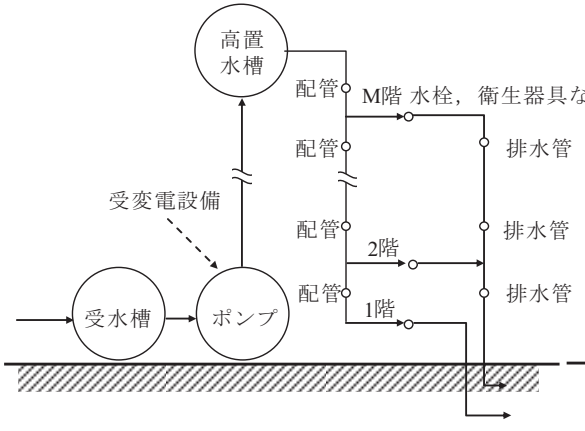

図 7 給排水・衛生設備の設備系統図

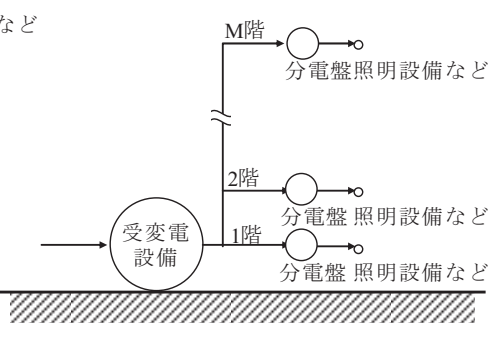

\begin{tabular}{|c|c|c|c|c|c|c|}
\hline \multicolumn{2}{|c|}{ 構造種別 } & None & Slight & Moderate & Extensive & e Complete \\
\hline \multicolumn{2}{|c|}{ 構造体 } & 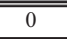 & 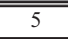 & 30 & 120 & 240 \\
\hline \multicolumn{2}{|c|}{ 非構造部材 } & 0 & \multicolumn{2}{|r|}{10} & \multicolumn{2}{|c|}{60} \\
\hline \multirow{4}{*}{$\begin{array}{l}\text { 衛 給 } \\
\text { 生排 } \\
\text { 設 水 } \\
\text { 備 · }\end{array}$} & 受水槽 & \multicolumn{3}{|c|}{0} & \multicolumn{2}{|c|}{90} \\
\hline & ポンプ & \multicolumn{3}{|c|}{0} & \multicolumn{2}{|c|}{90} \\
\hline & 配管 & \multicolumn{3}{|c|}{0} & \multicolumn{2}{|c|}{30} \\
\hline & 衛生器具 & \multicolumn{3}{|c|}{0} & \multicolumn{2}{|c|}{10} \\
\hline \multirow{3}{*}{$\begin{array}{l}\text { 電 } \\
\text { 気 } \\
\text { 設 } \\
\text { 備 }\end{array}$} & 受変電設備 & \multicolumn{3}{|c|}{0} & \multicolumn{2}{|c|}{90} \\
\hline & 分電盤 & \multicolumn{3}{|c|}{0} & \multicolumn{2}{|c|}{30} \\
\hline & 照明器具 & \multicolumn{3}{|c|}{0} & \multicolumn{2}{|c|}{10} \\
\hline
\end{tabular}

図 8 電気設備の設備系統図
表 4 被害状態に応じた修復期間 
が増加しているにも拘らずリスクの大きさが増加する理由は，地震 動および建築物の振動特性の関係により, 応答変形の低減具合と比 較して応答加速度の増加具合が大きくなり, 主に加速度に依存する 設備機器の被害が大きくなったためである。この考察に関する詳細 は第 7 章において示す。

（3）地震リスクに基づく耐震性能（評価結果）

本論文では, 第 4 章に前述した通り, 建築物の耐震性能は基準値 の倍数として各地震リスクの大きさを基準化し, その最大值により 評価する。ここで，基準值の設定は重要であるが，現段階では世の 中の相場や考え方が定まっていないため, 本論文では意思決定者の 許容值の例として, 人的被害率は $0.001(0.1 \%)$, 損失率は $0.1(10 \%)$, 機能停止期間は 30 日を設定した。

基準化した各地震リスクの 50 年 10\%超過值（以下，基準化リス クと呼ぶ）および建築物の耐震性能評価結果を図 11 に示寸。図よ
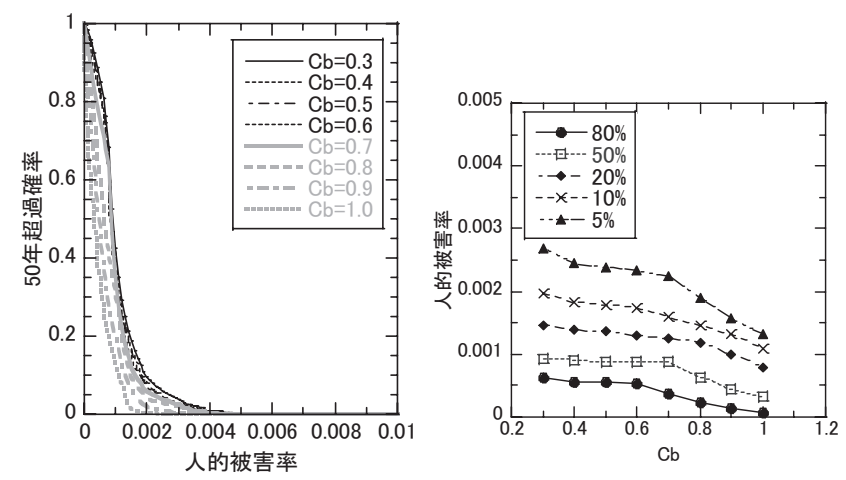

a)人的被害率
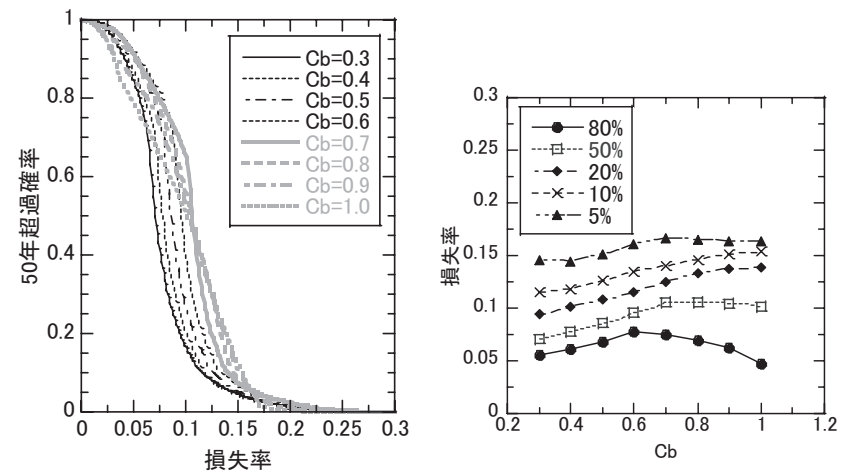

b)損失率
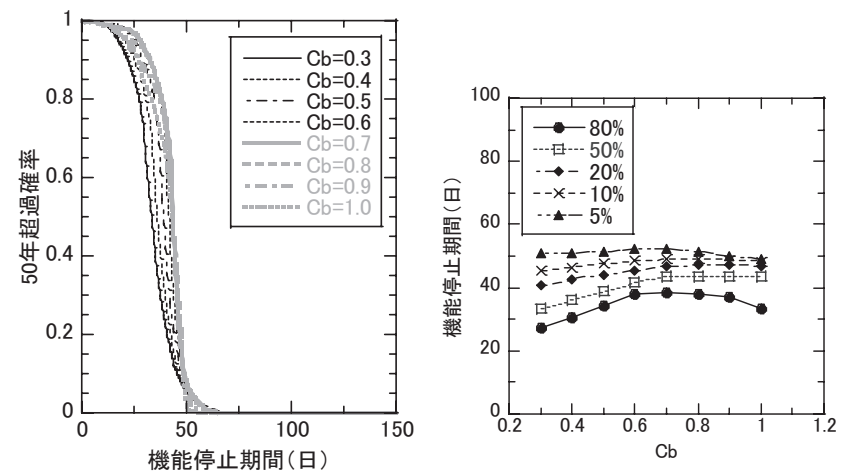

c)機能停止期間

図 10 地震リスク曲線（左）および $C_{b}$ による地震リスク值 （50 年超過確率 $80 \%, 50 \%, 20 \%, 10 \%, 5 \%$ ）の変化（右）
り，耐力 $\left(C_{b}\right)$ の増加に伴い，基準化リスクにおける人的被害率の 大きさは単調減少し，損失率は単調増加し，機能停止期間は同程度 となっている様子が認められる。そのため, 地震リスクの観点から 見た耐震性能は， $C_{b}$ が 0.7 程度までは耐力が増加寸るほど向上し， 実際には可能性は少ないが $C_{b}$ が仮にそれ以上に強くなったとして も耐震性能は頭打ちとなる。このように，建築物に係る評価条件に よっては，人的被害率，損失率および機能停止期間の地震リスクの 大きさはトレードオフの関係になる可能性がある。これは即ち，多 面的に地震リスクを捉えて耐震性能を評価し，それに基づき耐震対 策を検討する必要性を示すものと考えられる。
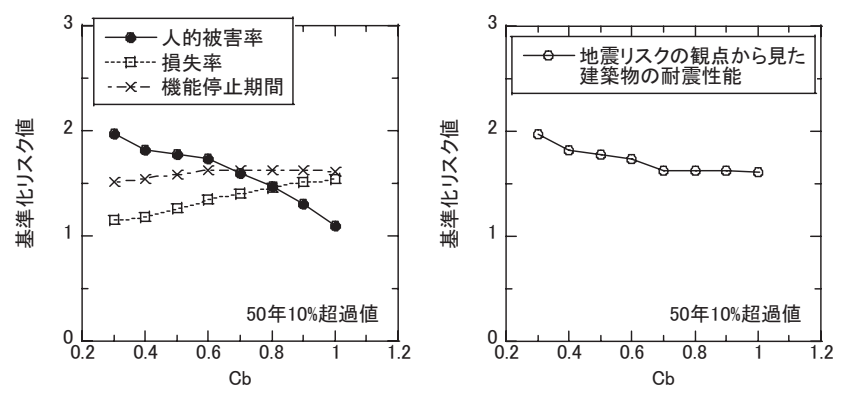

図 11 基準化した各地震リスクの変化（左）と 地震リスクに基づく建築物の耐震性能の変化（右）

\section{2 地盤条件の違いによる耐震性能評価結果への影響 \\ (1) 評価条件}

地盤構造モデルとして, 表 5 に示寸第 1 種地盤（地盤 1 ）および 第 3 種地盤（地盤 3）を設定し11）６.1 と同様の評価を行う。なお， 以下， 6.1 の評価で用いた地盤構造モデル（表 2) は地盤 2 と呼ぶ。 また，建築物モデルは 6.1 の検討と同様に, ベースシア係数 $C_{b}$ が $0.3 \sim 1.0$ の 3 階建の建築物モデル（計 8 通り）を用いる。その他の 評価条件は第 5 章に示した通りである。

表 5 地盤構造モデル

a)地盤 1

\begin{tabular}{|c|c|c|c|c|c|c|}
\hline & $\begin{array}{c}\text { 底面深度 } \\
\mathrm{D}(\mathrm{m})\end{array}$ & $\begin{array}{c}\text { 層厚 } \\
\mathrm{H}(\mathrm{m})\end{array}$ & $\begin{array}{c}\text { 密度 } \\
\rho(\mathrm{t} / \mathrm{m} 3)\end{array}$ & $\begin{array}{c}\mathrm{S} \text { 波速度 } \\
\mathrm{Vs}(\mathrm{m} / \mathrm{s})\end{array}$ & $\begin{array}{c}\mathrm{P} \text { 波速度 } \\
\mathrm{Vp}(\mathrm{m} / \mathrm{s})\end{array}$ & 土質 \\
\hline \hline 1 & 3.2 & 3.2 & 1.7 & 130 & 320 & 砂質土 \\
\hline 2 & 5.7 & 2.5 & 1.8 & 340 & 720 & 砂質土 \\
\hline 3 & 10.0 & 4.3 & 1.7 & 280 & 720 & 粘性土 \\
\hline 4 & 17.6 & 7.6 & 1.9 & 380 & 1980 & 砂質土 \\
\hline 工学的基盤 & & & 2.1 & 510 & 1980 & \\
\hline
\end{tabular}

b)地盤 3

\begin{tabular}{|c|c|c|c|c|c|c|}
\hline & $\begin{array}{c}\text { 底面深度 } \\
\mathrm{D}(\mathrm{m})\end{array}$ & $\begin{array}{c}\text { 層厚 } \\
\mathrm{H}(\mathrm{m})\end{array}$ & $\begin{array}{c}\text { 密度 } \\
\rho(\mathrm{t} / \mathrm{m} 3)\end{array}$ & $\begin{array}{c}\text { S波速度 } \\
\mathrm{Vs}(\mathrm{m} / \mathrm{s})\end{array}$ & $\begin{array}{c}\mathrm{P} \text { 波速度 } \\
\mathrm{Vp}(\mathrm{m} / \mathrm{s})\end{array}$ & 土質 \\
\hline \hline 1 & 17.7 & 17.7 & 1.8 & 130 & 1410 & 粘性土 \\
\hline 2 & 28.5 & 10.8 & 1.9 & 250 & 1550 & 砂質土 \\
\hline 3 & 36.1 & 7.6 & 1.9 & 360 & 1650 & 砂質土 \\
\hline 工学的基盤 & & & 1.9 & 430 & 1650 & \\
\hline
\end{tabular}

（2）地震リスクに基づく耐震性能（評価結果）

地盤 1 および地盤 3 について, 各建築物モデルの人的被害率，損 失率および機能停止期間の地震リスク曲線を評価し, 6.1 と同様の 基準值により基準化した地震リスクの 50 年 $10 \%$ 超過值を算定した。 
評価結果を図 12 に示す。また, 地震リスクに基づく耐震性能評価 結果を地盤 1 , 地盤 2 および地盤 3 について比較して図 13 に示す。

図 12 より, 地盤 1 では, 耐力 $\left(C_{b}\right)$ の増加に伴い, 基準化リス クにおける人的被害率の大きさは単調減少するが, 損失率はやや単 調増加，機能停止期間は同程度となっており，全性能の中では何れ の $C_{b}$ においても機能停止期間が最大となっている。一方で，地盤 3 では, 基準化リスクにおける人的被害率の大きさは特定の $C_{b}$ 以上に なると急減し, 損失率および機能停止期間は極小值を持つ変化が認 められ，全性能の中では $C_{b}$ が 0.6 以下の場合は人的被害率が，それ 以上の場合は機能停止期間が最大となっている。

これより，同じ設計の建築物でも地盤条件の違いにより，人的被 害率，損失率および機能停止期間の地震リスクの大きさおよびその 相対的な関係は大きく異なることが確かめられた。

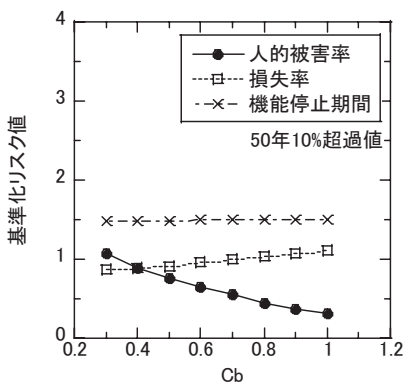

a) 地盤 1

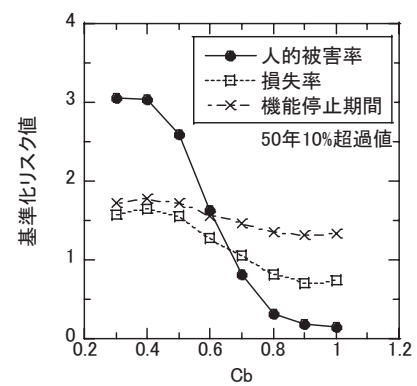

b) 地盤 3
図 12 基準化した各地震リスクの変化（地盤 1 ，地盤 3 )

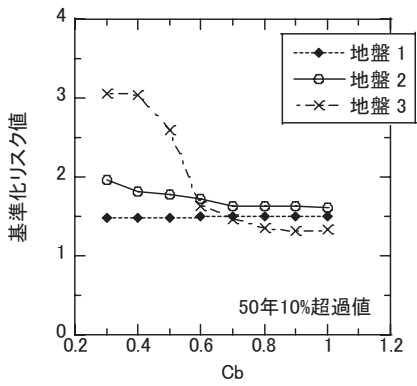

図 13 地盤条件の違いによる建築物の耐震性能の変化

\section{7. 評価結果の考察}

第 6 章において各性能に関寸る地震リスク評価結果の大きさが卜 レードオフの関係になる可能性を示したが, その理由を, 地震動お よび建築物の振動特性の相互関係による地震リスクに対する構造体, 非構造部材および設備機器の影響度の変化に着目して, 物理的に解 釈する。

\section{1 地震リスクに対する各構成要素の影響度の評価方法}

\section{(1) 損失率の地震リスク}

地震八ザードの分野では, 地震八ザード曲線に大きな影響を与え る地震発生源を特定し, 地震ハザードに適合した想定地震の諸元を 評価する “地震八ザードの再分解”という方法が従来から用いられ ている例えば 27)。近年, この概念を地震リスクに応用した研究も行わ れ始めている例えば 28)。本論文では，再分解の概念に基づき，地震り スクに対する各構成要素の影響度を評価する。つまり，地震リスク
曲線は建築物周辺の全ての地震およびそのばらつきを考慮して評価 した建築物全体の損失率を集約したものであるのに対して，これを 構造体, 非構造部材および設備機器の損失率の単位に分解すること により影響度を評価する。以下，このような処理を地震リスクの再 分解と呼ぶことにする。

具体的には，損失率の地震リスク曲線を 50 年超過確率 $0.0 \sim 1.0$ の範囲で 20 等分し, 各超過確率の区間において含まれる全計算厅 一スについて各構成要素の損失率の期待值を算出する（図 14）。こ こでは, これを損失率の地震リスクにおける各構成要素の影響度と する。

（2）人的被害率の地震リスク

人的被害率の地震リスクは構造体の損傷のみにより評価されたも のである。したがって, 地震リスク評価結果（図 10a） そのものが 構造体の影響度を示す。

（3）機能停止期間の地震リスク

各計算ケースにおいて, 対象とする構成要素の被害がゼロであっ たと仮定した場合の機能停止期間の低減日数を算出する。機能停止 期間の地震リスク曲線に対する各構成要素の影響度は, 地震リスク の再分解を用いて算出した, 各構成要素の低減日数の期待值により 評価する。

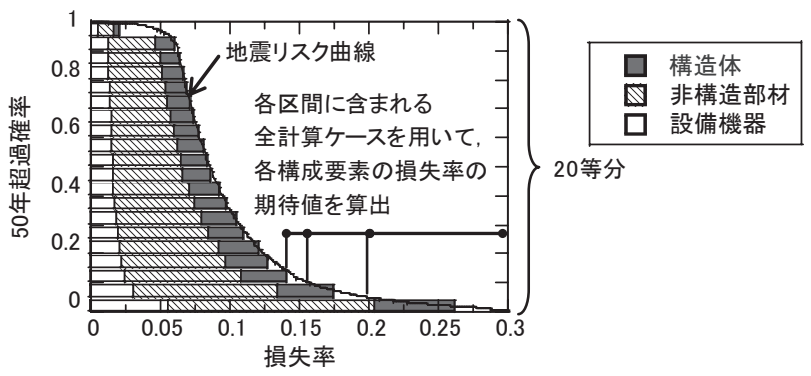

図 14 損失率の地震リスクに対する各構成要素の影響度 (地震リスクの再分解)

\section{2 地震リスクに対する各構成要素の影響度}

6.1 の評価結果を考察するため, 地震リスク曲線に対する構成要 素の影響度を評価した。極端な例として， $C_{b}=0.3$ および $C_{b}=1.0$ に ついての損失率および機能停止期間の地震リスクの再分解結果を図 15 および図 16 に示す。なお, 図 15 および図 16 の縦軸の 50 年超 過確率は, 再分解の対象とした地震リスク曲線の值であることに注 意されたい。これらの図より, 損失率については, $C_{b}=0.3$ では構造 体および非構造部材の影響度が設備のそれよりも大きいが， $C_{b}=1.0$ では設備の影響度が増大し，構造体および非構造部材のそれは減少 していることが分かる。また，機能停止期間についても， $C_{b}=0.3$ で は構造体の影響度が最も大きいが, $C_{b}=1.0$ では構造体の影響度は減 少し, 給排水・衛生設備のそれが最も大きくなることが確認できる。 この理由は, 詳細は後述するが, $C_{b}$ の増加に伴い応答変形は減少す るが，応答加速度は増加することによる。

次いで, 全ての $C_{b}$ について 50 年 $10 \%$ 超過值における構成要素の 影響度の变化を図 17 に示す。図から, 変形依存である構造体およ び非構造部材については, 損失率，機能停止期間の地震リスクの何 れにおいても単調減少しているのに対し, 加速度依存である設備に 
ついては, 単調増加していることが分かる。また, 人的被害率の地 震リスク (図 10 の a) ) は構造体の影響のみによるものであるが, 単調減少の傾向が認められる。このように, 耐力 $\left(C_{b}\right)$ の増加に伴 い各構成要素の被害は必ずしも減少するとは限らず，その程度は評 価条件によって複雑に変化する。人的被害率, 損失率および機能停 止期間の地震リスクは各構成要素の被害のバランスを異なる切り口 で評価したものであるため, 第 6 章の検討において各性能に関する 地震リスクの大きさがトレードオフ関係になるという現象が生じた ものと考えられる。

\section{3 地震動之建築物の振動特性の相互関係の影響}

地震リスクに対する構成要素の影響度が変化する理由を, 地震動 と建築物の Sa-Sd 曲線の関係に着目して考察する。ここでは, 地震 リスクの 50 年 $10 \%$ 超過值という被害程度が比較的大きな現象を考 察するため, 震源モデルはマグニチュード $(\mathrm{Mw}) 7.5$, 震源最短距 離（X） $10 \mathrm{~km}$, 深さ（D） $10 \mathrm{~km}$ を設定する。なお, 距離減衰式の ばらつきは考慮しない。その他の評価条件は 6.1 の評価と同様であ る。地表および工学的基盤応答スペクトル, 地震動および建築物の Sa-Sd 曲線の関係を図 18 に示す。

図 17 において, 変形依存である構造体および非構造部材の影響 度は耐力 $\left(C_{b}\right)$ の増加に伴い減少傾向にあり, 加速度依存である設 備機器の影響度は単調増加している理由は, 図 18 の地震動および 建築物の Sa-Sd 曲線の交点が建築物の応答值を与えていることによ り説明できる。応答加速度は $C_{b}$ が増加するにつれて増大寸る一方で, 応答変形は $C_{b}$ が $0.3 \sim 0.8$ では地震動の卓越周期（ピーク）の影響 で変形は進まないが, それ以上に $C_{b}$ が大きくなるとピークの影響を 受けにくくなり変形が大幅に減少する様子が確認できる。

\section{8. 結び}

本論文では, 地震リスクの観点からの安全性, 修復性および使用 性を総合した建築物の耐震性能評価手法を構築した。提案手法にお いて, 地震リスクの観点からの安全性については人的被害率, 修復 性については損失率，使用性については機能停止期間の地震リスク 曲線を評価項目として設定し, 建築物の耐震性能は各性能に関する 地震リスクの大きさを同一の尺度に揃えた上でその最大值（最悪の 被害）により評価することとした。また，損失率の地震リスクは既 報 8)に基づき評価し，人的被害率および機能停止期間の地震リスク 評価に関しては新たに評価手法を構築した。本論文において全体の 評価手法を一通り構築したことに意義があると考える。

さらに，地盤および建築物に関する評価条件を変化させ，提案手 法によるパラメトリックスタディを行うと共に，地震動および建築 物の振動特性の相互関係による地震リスクに対する構造体, 非構造 部材および設備機器の影響度の変化に着目して評価結果を物理的に 解勫した。ここで, 地震リスクに対する各構成要素の影響度は, 地 震リスクの再分解の概念を利用して評価することとした。本論文の 検討ケースについて考察した結果を以下に示す。

・ 人的被害率, 損失率および機能停止期間の地震リスクの大きさ はそれぞれ複雑に変化し，トレードオフの関係になる可能性が あることが確かめられた。またその結果, 耐力を増加しても各 性能の地震リスクを総合した建築物の耐震性能は頭打ちにな る場合があることを定量的に示した。これは即ち, 本研究の着

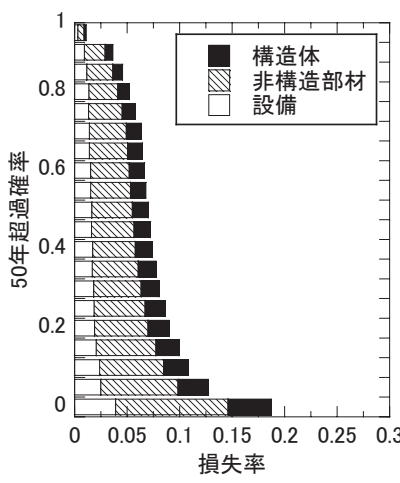

a) $C_{b}=0.3$

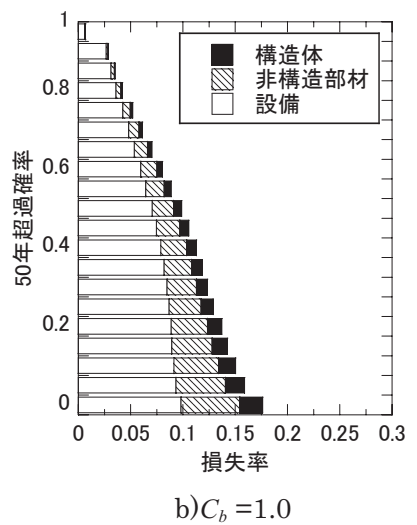

b) $C_{b}=1.0$
図 15 損失率の地震リスクに関する再分解結果

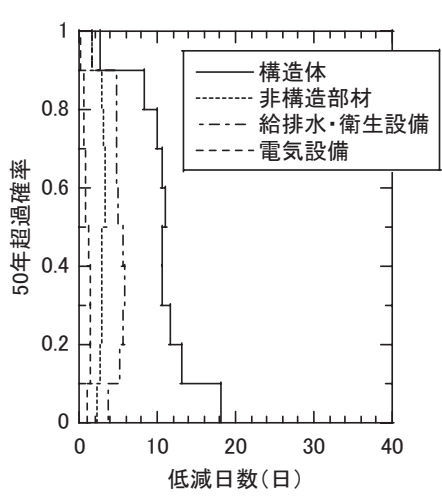

a) $C_{b}=0.3$

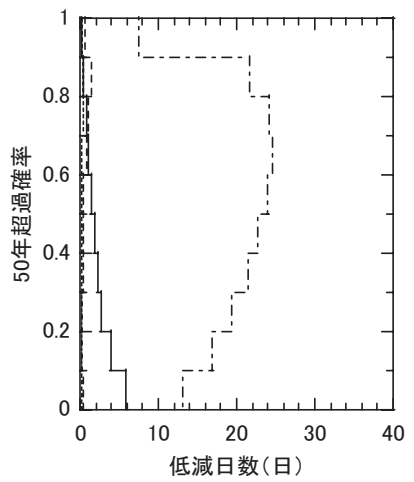

b) $C_{b}=1.0$
図 16 機能停止期間の地震リスクに関する再分解結果

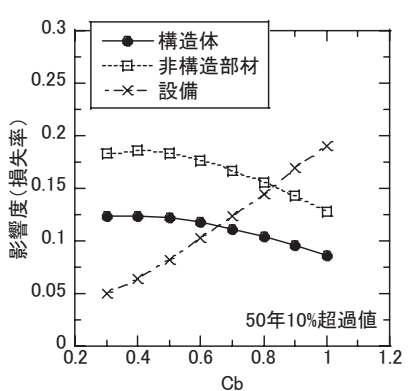

a) 損失率

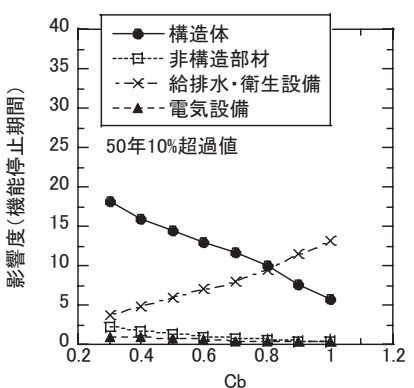

b)機能停止期間
図 17 各構成要素の影響度の変化（50 年 $10 \%$ 超過值）
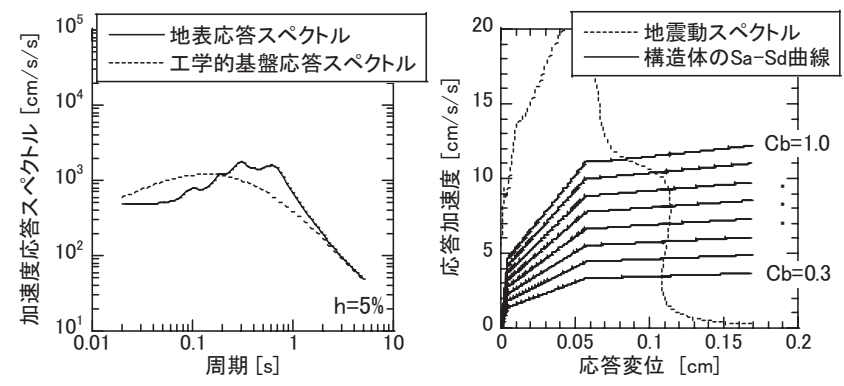

図 18 地震応答スペクトル（左） と 地震動および建築物の Sa-Sd 曲線の関係（右）

$(\mathrm{Mw}=7.5, \mathrm{X}=10 \mathrm{~km}, \mathrm{D}=10 \mathrm{~km})$ 
目点である多面的に地震リスクを捉えて耐震性能を評価し，そ れに基づき耐震対策を検討する必要性を示唆するものと考え る。

- 人的被害率の地震リスクの大きさは耐力増加に伴い単調減少 する一方で, 損失率および機能停止期間の地震リスクの大きさ は一部の検討ケースで増大寸る傾向が認められた。この現象が 生じた理由を地震動および建築物の Sa-Sd 曲線の関係を用い て検討した結果, 応答変形は減少傾向にあるが応答加速度は増 大し, 変形依存の構造体および非構造部材の被害の低減具合と 比較して, 加速度依存の設備機器 (特に, 給排水・衛生設備) の被害の増大具合が大きかったためであることが定量的に確 かめられた。

- 上述の知見から, 構造体の耐力増加型の耐震補強と併せて, 設 備機器の補強あるいは健全性の確認を実施することも重要で あることが示唆される。

残された課題として以下の項目が挙げられる。地震リスクの観点 から建築物の耐震性能を評価寸る場合, 本研究で示した評価関数以 外にも様々なものが考えられ, 意思決定者に応じて適切な関数を使 い分けることも有用である。その他の評価関数については今後の検 討課題と寸る。また, 本研究は多くの要素技術が関わり, 様々な入 カデータおよび仮定条件を設定している。これらの仮定条件等が評 価結果に与える影響についても感度解析等を行うことにより今後検 討していきたい。

\section{参考文献}

1) Applied Technology Council (ATC) : Guidelines for Seismic Performance Assessment of Buildings ATC-58 50\% Draft, 2009.04

2）建設省大臣官房技術調查室監修（社）建築研究振興協会編：建築構造に おける性能指向型設計法のコンセプト一仕様から性能へ一, 技報堂出版, 2000.

3）損害保険料率算出機構：地震危険度指標に関寸る調查研究一地震 PML の現状と将来一, 2002 .

4）諏訪仁, 野畑有秀, 関松太郎：兵庫県南部地震の被災データベースを用 いた既存建築物の地震リスク評価に関する研究, 日本建築学会技術報告集, 第 12 号, pp.41-46, 2001.01

5）高橋雄司, 正木信男, 穴原一範, 五十田博 : 地震危険度の高い地域の建 物を対象とした地震リスク・マネジメント, 日本建築学会構造系論文集, 第 591 号, pp.25-33，2005.05

6）石田寬, 源栄正人：地盤増幅特性を考慮した一様ハザードスペクトルに 基づく建築構造物の地震リスク評価手法, 日本建築学会構造系論文集, No.583, pp.23-30, 2004.09

7) 安中正, 山崎文雄, 片平冬樹: 気象庁 87 型強震記録を用いた最大地動及 び応答スペクトル推定式の提案, 第 24 回地震工学研究発表会講演論文集, pp.161-164, 1997.07

8）清水友香子, 源栄正人, 石田寛: 地震リスクにおける構造一非構造部材 の寄与に着目した建築物の耐震性能評価, 日本建築学会構造系論文集, Vol.75, No.658, pp.2125-2132, 2010.12

9）地震調查研究推進本部 : 全国を概観した地震動予測地図, 2008 .

10）内山康生, 翠川三郎 : 震源深さの影響を考慮した工学的基盤における応 答スペクトルの距離減衰式, 日本建築学会構造系論文集, 第 606 号, pp.81-88, 2006.08

11）日本建築学会 : 建物と地盤の動的相互作用を考慮した応答解析と耐震設 計, 2006.02

12) Hardin, B. O. and Drnevich, V. P.: Shear Modulus and Damping in Soils: Design Equations and Curves, Proc. ASCE, SM7, pp.667-692, 1972.
13）石田寬: 応答スペクトル法による地盤增幅特性を考慮した地震動評価手 法の比較, 日本建築学会大会学術講演梗概集, B-2 分冊, pp.121-122, 2006.09

14）国土交通省住宅局建築指導課ほか：2001 年度限界耐力計算法の計算例 とその解説, ぎょうせい, 2001.

15) Wolf, J.P: Fundation Vibration Analysis Using Simple Physical Models, Prentice-Hall, 1994.

16) Federal Emergency Management Agency (FEMA): HAZUS-MH MR3 Multi-hazard Loss Estimation Methodology Technical Manual Earthquake Model, 2003.

17）生田英輔, 宮野道雄, 糸魚川栄一, 西村明儒, 田中裕, 梶原浩一, 熊谷 良雄: 統合データベースに基づく兵庫県南部地震による人的被害の発生機 構に関する分析, 日本建築学会計画系論文集, 第 590 号, pp.117-123, 2005.04

18) Kawasumi H: Intensity and Magnitude of shallow Earthquakes, Beresu Central Seism. Intern. Ser. A, Trav, Sci., 19, pp.99-114, 1954.

19）岡田成幸: 地震時の室内変容に伴う人的被害危険度評価に関する研究一 その 1 居住空間危険度マイクロゾーニングの提案一, 日本建築学会構造系 論文集，第 454 号，pp.39-49，1993.12

20）杉本寛子, 山崎文雄, 西村明儒, 浅野進一郎 : 芦屋市における兵庫県南 部地震の建物被害と人的被害の関係, 地域安全学会論文集, pp.266-271, 1998.10

21）梅村幸一郎，村尾修，山崎文雄，西村明儒：GIS を用いた灘区における 人的被害と建物被害の相関分析，地域安全学会梗概集，pp.64-67，1999.11

22）西村明儒, 大西一嘉：1995 年兵庫県南部地震による人的被害（その 7) 中高層住宅での死亡原因に関する考察, 日本建築学会大会学術講演梗概集, F-1 分冊, pp.815-816, 1997.06

23）中村孝明, 遠藤透：BCP への貢献を目的とした建物の機能確保に関す る研究, 総合論文誌, No.7, pp.87-92, 2009.01

24）境茂樹, 加藤貴司 : 建築設備の機能停止を考慮したオフィスビルの地震 リスク評価事例, pp.310-313, 日本地震工学会大会梗概集, 2008

25）坂本成弘：事務所ビルの地震後復旧曲線, 日本建築学会大会学術講演梗 概集，B-1 分冊，pp.65-66，2007.08

26）荷福努，川上洋介，中村孝明：BCP に資する機能停止期間の評価モデ ル, 第 57 回理論応用力学講演会, pp.131-132, 2008.06

27) Jack W. Baker: An Introduction to Probabilistic Seismic Hazard Analysis (PSHA) version 1.3, 2008.10.

28) H. P. Hong and K. Goda: A Comparison of Seismic-Hazard and Risk Deaggregation, Bulletin Seismological Society of America, Vol.96, No.6, pp.2021-2039, 2006.12.

（2011年 5 月 9 日原稿受理，2011年10月26日採用決定） 